\title{
Financial - Banking Exclusion - an Economic and Social Phenomenon
}

\author{
Gabriela PASCU (POPESCU) ${ }^{\star}$, Lavinia COSTAN (POPA) ${ }^{\star \star}$
}

\begin{tabular}{l}
\hline \multicolumn{1}{c}{ A R T I C L E I N F O } \\
\hline Article history: \\
Accepted November 2019 \\
Available online December 2019 \\
\hline JEL Classification \\
G20, I32, P36, P46 \\
Keywords: \\
Financial-banking exclusion, Social \\
exclusion, Banking disponibility, \\
Financial inclusion \\
\hline
\end{tabular}

\begin{abstract}
A B S T R A C T
Financial-banking exclusion deprives some categories of people from having access to financial-banking services. It is a phenomenon that has global alarming efects and it has special implications in the discrepances that exist between different categories of people regarding incomes, economical development and social wellness of population. In this research the authors have studied the financial-banking phenomenon, factors that influence it and have identified solutions for decreasing the financial-banking exclusion and its implications at social level.
\end{abstract}

(C) 2019 EAI. All rights reserved.

\section{Introduction}

Competition between banks for gaining customers and increasing market share, determined banking institutions to diversify their offer of products and services while providing competitive prices. In a dinamic market, with important economical growths, banks are struggling to gain new customers and to diversify the products' portfolio for existing customers. Coccorese (2004) stated that competion has proved to be stronger in those areas where macroeconomical data indicate a dynamic economy.

Amaeshi et al. (2007) said that in order to attract as many customers as they can and maximize net income, banks try to improve their market strategies and reduce costs of products and services. Inevitable, these approches have excluded some people from having access to certain financial services.

\section{Literature review}

According toh Anderloni et al (2008), financial exclusion relates to the process that population faces in accessing and/or using financial products and services that they need and that allow a normal life in society.

The literature review in Romania is very limited, while this subject is often debated worldwide.

\subsection{Financial-banking exclusion worldwide}

According to Hodgson (2017)., worldwide, two billion persons do not have a banking account or access to a financial-banking institution by using their mobile phones or any other banking device. More than 20 percent from population who does not have access to banks get monthly salary or other cash transfers and a lot of people from developing counties pay bills and school taxes in cash.

According to the same study performed by Hodgson (2017), 94 percent from adults in developed counties have an open bank account in 2014, while only 54 percent from adults in developing countries have a bank account. Countries in Middle East have the lowest rate for people using a bank, 14 percent. Main reason why people do not have an open banking account is that they do not have enough funds, while only 4 percent said that they do not want to have an account.

\subsection{Banking exclusion in Romania}

Banking exclusion is a phenomena that has been poorly analized in Romania as compared to the studies performed woldwide. The banking exclusion concept (in Romanian context) was studied by Popescu, B.B. (2015) în his PhD thesis. According to him, „an important dimension of banking exclusion, and on this basis a component of the expanding or restraining network distribution" offered by banks is bank availability". He calculated the bank availability as the number of branches weighted by $2 / 3$ plus the number of de ATMs weighted by $1 / 3$. 
Popescu, B.B. has determined a statistical model that explains criteria used by banks to measure up network distribution, taking into consideration certain indicators (unemployment rate, average salary, gross domestic product). Popescu (2015) has come to the conclusion that "counties where there is a low number of branches and ATMs will have the lowest availability banking inbex, while the higest availability index will be in the counties with more branches and ATMs".

From on year to another, banks that operate in Romania have narrowed their activity, closing more branches and ATMs. Some branches have closed their activity or mergered with other banks.

According to the Romanian National Bank (2017) at the end of 2017 banks with private majority capital had the highest weight in the total number of credit institutions (74 percent), followed by the institutions with foreign majority capital (20 percent) and finally by stated owned credit institutions (6 percent).

According with the annual report made by the National Bank of Romania (2017), in terms of net assets, the first position is taken by the Romanian Commercial Bank, with 14 percent, followed by Transilvania Bank (12 percent), Romanian Development Bank Groupe Societe Generale (11 percent), Unicredit (8 percent) and Raiffeisen Bank with 7 percent (see figure 1 below).

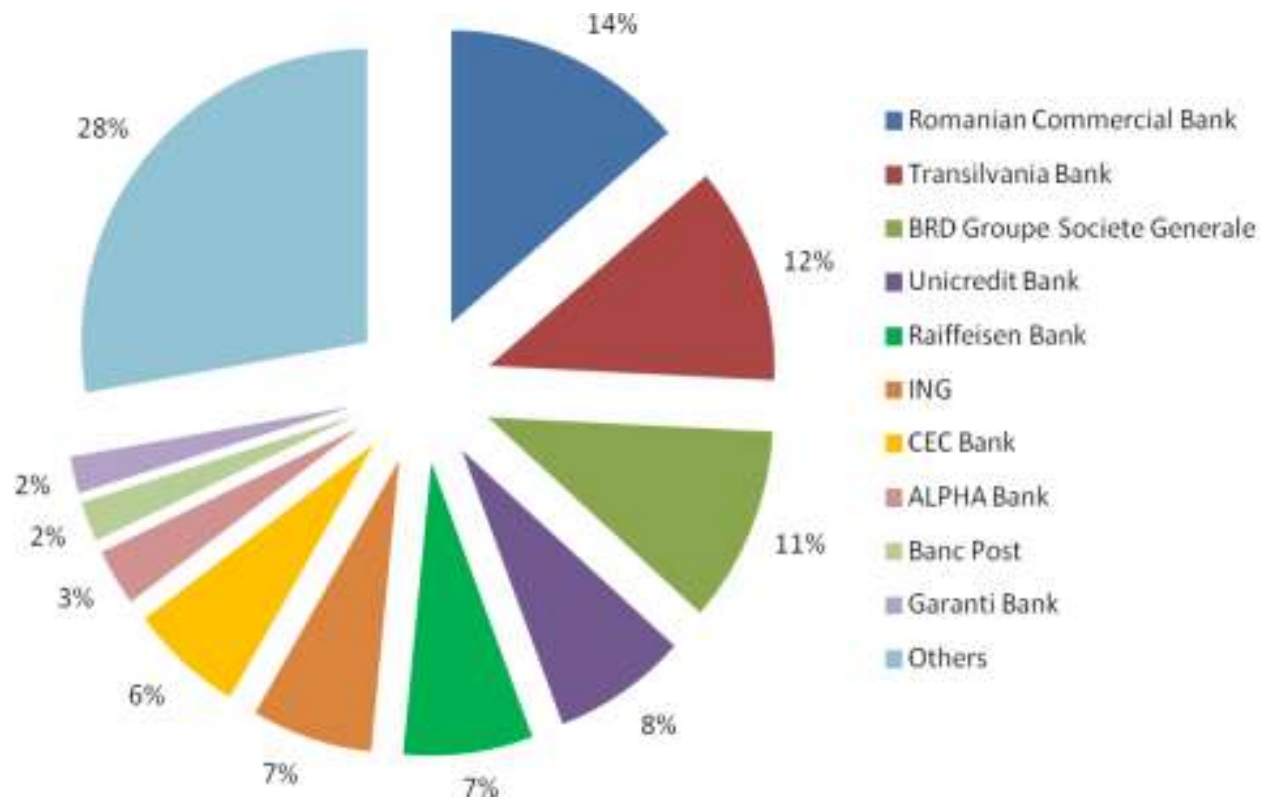

Figure 1. Banks ranked after their net income asset in 2017 Source: National Bank of Romania

Reducing the number of branches and ATMS available in each geographical region, has direct consequences on excluding people from having access to banks. There are also other factors that contribute to increasing the financial-banking exclusion, such as:

- Banks' taxes (only few banks offer their customers accounts with no administration fees, no fees at cash withdrawals from ATMs, and zero fees are applying only if the account holder receive the salary in the bank account);

- Conditions that may apply (especially in case of loan products) such as: minimum/maximum age, studies, minimum income, minimum period of employment, marital status, number of children a.s.o.;

- Proximity of bank network (there are situations when a person has to go big distances to reach a bank);

- $\quad$ Access to a computer with internet connection (this is the situation in case of retired people, mostly);

- Non-confidence in financial-banking system (some people prefer not to open any account for receiving their salary, pensions or paying current bills).

The solution for decreasing the financial exclusion is the financial inclusion. A first step in increasing the financial-banking inclusion is to own a bank account. This has an important role in security and transparency of funds administration.and contributes to transactions efficiency.

However, owning a bank account is not sufficient. It is necessary that the direct involvment of the stat is needed. This could be possible by using legistalive policies, that contribute to the reduction of social exclusion and consequently, to the financial-banking exclusion of some categories of people, by providing an adequate environment for banking inclusion. This could be possible by encouraging competitice prices, 
marketing polices and last but not the least by educating the population about using banking products and services.

Financial-banking education is modest in Romania (with the exception of economic high shools and universities, where students learn at least from the theoretical point of view, basic economic knowledge).

However, there are institutions that are activley involved in promoting financial education among population and especialy among young people.. One of these organisations is Romanian Banking Institute that organizes together with the main Romanian banks seminars that debate aspects concerning financial education. Participants benefit from useful informations concerning economic and financial base, the way that these terms work in the everyday activity, advantages of using in an efficient way the financial services, as well as more complex issues for those people that are interested.

\section{Methodology}

Using public information that are available on the Romanian banking sites, National Institute of Statistics, as well as available previous researches concerning financial-banking exclusion, the authors have identified factors that contribute to the rapid development of social and financial exclusion as well as the main solutions for decreasing this phenomenon.

The objective of the research was to determine the main indicators and their direct or indirect correlation with the social and financial exclusion.

Analysing the information provided by the National Institute of Statistics at the end of 2017 and using regression method and SPSS software, the authors identified some correlations between social exclusion and some statistical indicators.

The research was made on a representative sample consisting of the 42 counties of Romania. The dependent variable included in the model was gross domestic product and the independent variables included were county area, number of inhabitans, average monthly wage, number of employed/unemployed persons, unemployment rate, number of retired persons (see table 1 below).

Table 1. Statistical indicators (2017 values)

\begin{tabular}{|c|c|c|c|c|c|c|c|c|}
\hline COUNTY & $\left|\begin{array}{c}\text { County } \\
\text { area }(\mathrm{km} 2)\end{array}\right|$ & $\begin{array}{l}\text { Number of } \\
\text { inhabitants }\end{array}$ & $\begin{array}{c}\text { Average } \\
\text { monthly } \\
\text { wage } \\
\text { (RON) }\end{array}$ & $\begin{array}{l}\text { Number of } \\
\text { employed } \\
\text { persons }\end{array}$ & $\begin{array}{c}\text { No of } \\
\text { unemployed } \\
\text { persons }\end{array}$ & $\begin{array}{c}\text { Unemployment } \\
\text { rate }(\%)\end{array}$ & \begin{tabular}{|c|} 
GDP/county \\
(million \\
RON \\
current \\
prices)
\end{tabular} & $\begin{array}{l}\text { Total } \\
\text { number of } \\
\text { retired } \\
\text { persons }\end{array}$ \\
\hline ALBA & $6,242.00$ & $379,608.00$ & $2,057.00$ & $162,100.00$ & $6,163.00$ & 3.70 & $13,561.60$ & $89,140.00$ \\
\hline ARAD & $7,754.00$ & $473,532.00$ & $2,103.00$ & $210,200.00$ & $3,245.00$ & 1.50 & $17,874.10$ & $107,095.00$ \\
\hline ARGES & $6,826.00$ & $643,573.00$ & $2,318.00$ & $249,700.00$ & $10,322 \cdot 00$ & 4.00 & $22,263.30$ & $153,843.00$ \\
\hline BACAU & $6,621.00$ & $745,805.00$ & $2,031.00$ & $197,700.00$ & $14,032.00$ & 6.60 & $15,630.70$ & $153,246.00$ \\
\hline BIHOR & $7,544.00$ & $618,793.00$ & $1,871.00$ & $260,400.00$ & $6,497.00$ & 2.40 & $18,804.40$ & $150,531.00$ \\
\hline \begin{tabular}{|l|} 
BISTRITA- \\
NASAUD \\
\end{tabular} & $5,355.00$ & $329,484.00$ & $1,815.00$ & $127,300.00$ & $4,043.00$ & 3.10 & $8,769.61$ & $63,199.00$ \\
\hline BOTOSANI & $4,986.00$ & $454,806.00$ & $1,887.00$ & $131,700.00$ & $4,919.00$ & 3.60 & $7,925.17$ & $98,449.00$ \\
\hline BRASOV & $5,363.00$ & $632,888.00$ & $2,314.00$ & $254,100.00$ & $7,353.00$ & 2.80 & $28,099.80$ & $146,091.00$ \\
\hline BRAILA & $4,766.00$ & $352,910.00$ & $1,859.00$ & $119,300.00$ & $6,294.00$ & 5.00 & $8,969.06$ & $88,424.00$ \\
\hline BUZAU & $6,103.00$ & $475,274.00$ & $1,903.00$ & $158,100.00$ & $15,001.00$ & 8.70 & $11,165.80$ & $125,438.00$ \\
\hline \begin{tabular}{|l|} 
CARAS- \\
SEVERIN \\
\end{tabular} & $8,520.00$ & $325,587.00$ & $1,869.00$ & $105,400.00$ & $3,961.00$ & 3.60 & $9,390.00$ & $75,267.00$ \\
\hline CALARASI & $5,088.00$ & $315,696.00$ & $1,940.00$ & $86,500.00$ & $4,487.00$ & 4.90 & $7,342.55$ & $70,736.00$ \\
\hline CLUJ & $6,674.00$ & $725,708.00$ & $2,668.00$ & $358,400.00$ & $7,460.00$ & 2.00 & $38,543.20$ & $179,169.00$ \\
\hline CONSTANTA & $7,071.00$ & $769,379.00$ & $2,117.00$ & $284,300.00$ & $9,099.00$ & 3.10 & $36,844.10$ & $151,631.00$ \\
\hline COVASNA & $3,710.00$ & $228,287.00$ & $1,858.00$ & $82,400.00$ & $3,612.00$ & 4.20 & $6,027.95$ & $48,090.00$ \\
\hline DAMBOVITA & $4,054.00$ & $526,906.00$ & $2,000.00$ & $181,300.00$ & $10,188.00$ & 5.30 & $14,286.40$ & $120,060.00$ \\
\hline DOLJ & $7,414.00$ & $697,675.00$ & $2,128.00$ & $242,500.00$ & $23,331.00$ & 8.80 & $19,398.40$ & $173,292.00$ \\
\hline GALATI & $4,466.00$ & $629,865.00$ & $2,007.00$ & $177,000.00$ & $15,245.00$ & 7.90 & $13,878.00$ & $140,267.00$ \\
\hline GIURGIU & $3,526.00$ & $275,840.00$ & $2,018.00$ & $79,300.00$ & $2,668.00$ & 3.30 & $7,450.73$ & $65,604.00$ \\
\hline GORJ & $5,602.00$ & $364,145.00$ & $2,137.00$ & $127,200.00$ & $8,600.00$ & 6,3 & $13,037.30$ & $80,845.00$ \\
\hline HARGHITA & $6,639.00$ & $333,218.00$ & $1,796.00$ & $128,400.00$ & $6,542.00$ & 4.90 & $8,667.11$ & $77,888.00$ \\
\hline HUNEDOARA & $7,063.00$ & $466,139.00$ & $1,898.00$ & $168,600.00$ & $7,898.00$ & 4.50 & $12,945.50$ & $127,399.00$ \\
\hline IALOMITA & $4,453.00$ & $292,170.00$ & $1,890.00$ & $88,100.00$ & $6,476.00$ & 6.90 & $7,479.41$ & $65,720.00$ \\
\hline IASI & $5,476.00$ & $930,518.00$ & $2,338.00$ & $282,700.00$ & $11,960.00$ & 4.10 & $25,362.40$ & $170,104.00$ \\
\hline MARAMURES & $6,304.00$ & $525,115.00$ & $1,886.00$ & $192,700.00$ & $6,186.00$ & 3.10 & $13,426.80$ & $117,301.00$ \\
\hline MEHEDINTI & $4,933.00$ & $285,011.00$ & $1,897.00$ & $94,400.00$ & $9,777.00$ & 9.40 & $5,958.19$ & $64,674.00$ \\
\hline MURES & $6,714.00$ & $595,326.00$ & $2,112.00$ & $225,500.00$ & $9,314.00$ & 4.00 & $17,344.40$ & $144,458.00$ \\
\hline NEAMT & $5,896.00$ & $575,595.00$ & $1,866.00$ & $171,500.00$ & $9,039.00$ & 5.00 & $11,217.80$ & $128,438.00$ \\
\hline OLT & $5,498.00$ & $446,140.00$ & $2,044.00$ & $149,800.00$ & $12,027.00$ & 7,4 & $9,923.29$ & $111,682.00$ \\
\hline PRAHOVA & $4,716.00$ & $804,348.00$ & $2,235.00$ & $284,500.00$ & $8,991.00$ & 3.10 & $33,840.20$ & $204,616.00$ \\
\hline
\end{tabular}




\begin{tabular}{|c|c|c|c|c|c|c|c|c|}
\hline COUNTY & $\begin{array}{c}\text { County } \\
\text { area }(\mathrm{km} 2)\end{array}$ & $\begin{array}{l}\text { Number of } \\
\text { inhabitants }\end{array}$ & $\begin{array}{l}\text { Average } \\
\text { monthly } \\
\text { wage } \\
\text { (RON) }\end{array}$ & $\begin{array}{l}\text { Number of } \\
\text { employed } \\
\text { persons }\end{array}$ & $\begin{array}{c}\text { No of } \\
\text { unemployed } \\
\text { persons }\end{array}$ & $\begin{array}{l}\text { Unemployment } \\
\text { rate (\%) }\end{array}$ & $\begin{array}{c}\text { GDP/county } \\
\text { (million } \\
\text { RON } \\
\text { current } \\
\text { prices) }\end{array}$ & $\begin{array}{l}\text { Total } \\
\text { number of } \\
\text { retired } \\
\text { persons }\end{array}$ \\
\hline SATU-MARE & $4,418.00$ & $390,227.00$ & $1,931.00$ & $143,000.00$ & $4,727.00$ & 3.20 & $9,947.15$ & $82,922.00$ \\
\hline \begin{tabular}{|l|} 
SALAJ \\
\end{tabular} & $3,864.00$ & $246,892.00$ & $1,891.00$ & $98,000.00$ & $4,821.00$ & 4.70 & $6,933.71$ & $61,733.00$ \\
\hline SIBIU & $5,432.00$ & $465,421.00$ & $2,315.00$ & $192,500.00$ & $4,770.00$ & 2.40 & $18,953.60$ & $99,466.00$ \\
\hline SUCEAVA & $8,553.00$ & $748,150.00$ & $1,876.00$ & $217,100.00$ & $12,379.00$ & 5.40 & $14,937.30$ & $152,315.00$ \\
\hline \begin{tabular}{|l|} 
TELEORMAN \\
\end{tabular} & $5,790.00$ & $384,343.00$ & $1,872.00$ & $132,400.00$ & $14,893.00$ & 10.10 & $7,580.20$ & $112,344.00$ \\
\hline \begin{tabular}{|l|} 
TIMIS \\
\end{tabular} & $8,697.00$ & $746,795.00$ & $2,562.00$ & $346,300.00$ & $3,540.00$ & 1.00 & $39,210.60$ & $156,708.00$ \\
\hline TULCEA & $8,499.00$ & $242,321.00$ & $2,009.00$ & $80,500.00$ & $3,951.00$ & 4.70 & $6,361.04$ & $49,003.00$ \\
\hline VASLUI & $5,318.00$ & $485,064.00$ & $1,877.00$ & $123,400.00$ & $14,239.00$ & 10.40 & $7,496.10$ & $97,491.00$ \\
\hline VALCEA & $5,765.00$ & $401,264.00$ & $1,854.00$ & $153,400.00$ & $6,670.00$ & 4.20 & $10,891.40$ & $107,177.00$ \\
\hline VRANCEA & $4,857.00$ & $390,148.00$ & $1,800.00$ & $130,400.00$ & $6,903.00$ & 5.00 & $8,285.55$ & $80,179.00$ \\
\hline Ilfov & $1,583.00$ & $407,626.00$ & $2,610.00$ & $191,100.00$ & $1,207.00$ & 0.60 & $21,936.70$ & $75,723.00$ \\
\hline Bucharest & $1,295.00$ & $2,103,251.00$ & $3,272.00$ & $1,177,600.00$ & $18,275.00$ & 1.50 & $200,165.00$ & $485,344.00$ \\
\hline TOTAL & $239,448.00$ & $21,851,235.00$ & $86,731.00$ & $8,366,800.00$ & $351,105.00$ & 182.70 & $818,125.62$ & $5,053,102.00$ \\
\hline AVERAGE & $5,701.14$ & $520,267.50$ & $2,065.02$ & $199,209.52$ & $8,359.64$ & 4.35 & $19,479.18$ & $421,091.83$ \\
\hline
\end{tabular}

Source: National Institute of Statistics

\section{Findings}

4.1. By using SPSS software, stepwise method, the output data showed that only three independent variables can be included in the model, having significant correlation with gross domestic product (dependent variable). These three independent variables are: number of employed persons, county area and total number of retired persons.

4.2. The R-square value of 0.983 indicates that 98.3 percent of the variation of GDP can be explained by variability of number of retired persons, number of employed persons and county area (see table below).

Table 2. R Square and Standard Error

\begin{tabular}{|c|c|c|c|c|}
\hline Model & R & R Square & $\begin{array}{c}\text { Adjusted R } \\
\text { Square }\end{array}$ & Std. Error \\
\hline 1 & $.984^{\mathrm{a}}$ & .969 & .968 & 5358.2895522 \\
2 & $.989^{\mathrm{b}}$ & .978 & .977 & 4567.2234267 \\
3 & $.991^{\mathrm{c}}$ & .983 & .982 & 4065.2507796 \\
\hline
\end{tabular}

4.3. The coefficients table below indicates that "number of employed persons" is positive correlated with "gross domestic product", while "county area and "total number of retired persons" are negative correlated with GDP. This means that gross domestic product increase when the number of employed persons increase, while GDP decrease when county area and number of retired persons increase.

4.4. The linear relationship among the variables is determined by analysis of variance. The value of $F$ is significant because statistical significance is 0.000 and this suggests a linear relationship among the variables, which means that the variables increase or decrease in like manner.

Table 3. Analysis of variance

\begin{tabular}{|ll|r|r|r|r|r|}
\hline Model & & \multicolumn{1}{|c|}{ Sum of Squares } & df & Mean Square & \multicolumn{1}{c|}{ F } & \multicolumn{1}{c|}{ Sig. } \\
\hline \multirow{2}{*}{1} & Regression & 35649975947.453 & 1 & 35649975947.453 & 1241.672 & $.000^{\mathrm{b}}$ \\
& Residual & 1148450677.028 & 40 & 28711266.926 & & \\
& Total & 36798426624.481 & 41 & & & \\
& Regression & 35984904961.141 & 2 & 17992452480.571 & 862.553 & $.000^{\mathrm{c}}$ \\
2 & Residual & 813521663.340 & 39 & 20859529.829 & & \\
& Total & 36798426624.481 & 41 & & & \\
& Regression & 36170428596.234 & 3 & 12056809532.078 & 729.554 & $.000^{\mathrm{d}}$ \\
3 & Residual & 627998028.247 & 38 & 16526263.901 & & \\
& Total & 36798426624.481 & 41 & & & \\
\hline
\end{tabular}

4.5. The dependent variables that are not statistically significant were excluded from the model.

4.6. The dependent variable (gross domestic product) is statistically correlated with the independent variables included in the model (number or retired persons, number of employed persons and county area), which means that the model is viable. 


\section{Conclusions}

Financial-banking exclusion is a phenomenon that is little approched in the speciality literature in Romania, although this issue is often analized worldwide.

The main factors that contribute to financial exclusion are bank's taxes, special conditions that banks may require, especially in case of loan products, proximity of bank network, access to a computer with internet connection, non-confidence in financial-banking system.

Analysing the information provided by the National Institute of Statistics at the end of 2017 and using regression method and SPSS software, the authors identified some correlations between social exclusion and some statistical indicators.

The research was taking into consideration same indicators that are correlated with the social exclusion (number of employed/unemployed persons, unemployment rate, gross domestic product, number of retired persons).

The research made by the authors indicates that the number of employed persons is positive correlated with gross domestic product, while county area and total number of retired persons are negative correlated with GDP. This means that gross domestic product increase when the number of employed persons increase, while GDP decrease when county area and number of retired persons increase. When number of employees increase, GDP increase, social exclusion decrease and financial inclusion increase.

Financial-banking institutions, by the price policies they used, state by legislative actions and other organisations that are direct involved, should colaborate for a common interest: that of reducing social exclusion of some people, in order to contribute to a social inclusion of these people, increase the standard of leaving and social welfare at the individual level and consequently at the global level.

\section{References}

1. Amaeshi, K.M., Ezeoha, A.E., Adi, B.C., Nwafor, M. (2007), Financial Exclusion and Strategic Corporate Social Responsibility: A missing link in sustainable finance discourse?, International Centre for Corporate Social Responsibility, Nottingham, p. 4-5.

2. Anderloni, L., Bayot, B., Bledowski, P., Iwanicz-Drozdowska, M, Kempson, E. (2008), Financial Services Provision and Prevention of Financial Exclusion. Accesed in January 10th at https://www.fi-compass.eu/sites/default/files/publications/financial-servicesprovision-and-prevention-of-financial-exclusion.pdf.

3. Coccorese, P. (2004), Banking competition and macroeconomic conditions: a disaggregate analysis, Journal of International Financial Markets, Institutions \& Money Vol. 14, p. 215-216.

4. Hodgson, C. (2019),The world's 2 billion unbanked, in 6 charts. Business Insider, 2017. Accessed in January 9th, 2019 at: https://www.businessinsider.com/the-worlds-unbanked-population-in-6-charts-2017-8, p.1-2.

5. Popescu, B.B. 2015), Using rating methods in banking products marketing-Phd. Thesis. The Academy of Economic Studies, Bucharest, Romania, p. 83-84.

6. Sarma, M., Pais, J. (2010), Financial Inclusion and Development. Journal of International Development, Vol. 23, Nr. 5, p. 618-620.

7. Romanian National Bank. Annual Report 2017. Accessed in January 5th 2018 at: http://bnr.ro/PublicationDocuments.aspx?icid=3043. 